\title{
BANK RESOLUTION 10 YEARS FROM THE GLOBAL FINANCIAL CRISIS: A SYSTEMATIC REAPPRAISAL
}

Emilios Avgouleas and Charles Goodhart

* Chair in International Banking Law and Finance, University of Edinburgh.

** Norman Sosnow Professor Emeritus, London School of Economics.

\section{Introduction}

Following the collapse of Lehman Brothers, a number of large interconnected financial institutions had to be bailed out because, faced with a dual liquidity and confidence crisis, they were struggling to sustain solvency and they were considered "too_big_to_fail" (TBTF). The decision to bail_out a number of major western financial institutions was taken over concerns about contagion in a disintegrating and highly vulnerable market, amidst a collapse of investor and user confidence and because most jurisdictions did not have legal and regulatory regimes to deal with the special requirements of bank failures outside of corporate insolvency laws.

Since 2010, most Group of Twenty (G20) jurisdictions, excluding China, have introduced new recovery and resolution regimes to deal with bank failures (for example, the United Kingdom and the European Union) or have revised the scope and funding of pre-existing regimes (for example, the United States). Apart from the Financial Stability Board's (FSB's) Key Attributes, ${ }^{1}$ which is a soft law document, resolution regimes worldwide have been enacted through legislation, namely in the European Union, ${ }^{2}$ the United Kingdom and the United States. ${ }^{3}$ The common objective of contemporary resolution regimes is, first, to facilitate the orderly failure of financial institutions in order to mitigate moral hazard and, second, to redirect the bulk of losses to the private sector, thereby eliminating the need for public bailouts. In contrast with corporate insolvency laws, which aim to maximize creditor satisfaction, the objectives of bank resolution regimes are to: secure operational continuity; stabilize the banking system by containing contagion through recapitalizing stressed institutions; and protect state funds by allocating losses to shareholders and debtholders, in the latter case through the use of debt-to-equity conversions or by writing_off liabilities through the

\footnotetext{
${ }^{1}$ FSB, "Key Attributes of Effective Resolution Regimes for Financial Institutions" (15 October 2014), online: <www.fsb.org/wp-content/uploads/r_141015.pdf>.

${ }^{2}$ EC, Directive 2014/59/EU of the European Parliament and of the Council of 15 May 2014 establishing a framework for the recovery and resolution of credit institutions and investment firms, [2014] OJ, L173/190 [BRRD].

${ }^{3}$ Title II of the Dodd-Frank Wall Street Reform and Consumer Protection Act of 2010, Pub L No 111-203, HR 4173.
} 
employment of the bail-in tool. ${ }^{4}$ Stringent creditor monitoring of bank risk is presumed to constrain excessive leverage ${ }^{5}$ because shareholders have strong incentives to increase leverage to maximize return on equity (ROE) ${ }^{6}$ The threat of a creditor bail-in should eliminate the TBTF subsidy $^{7}$ that banks enjoy by raising the ex ante cost of bank funding. This, in principle, should also contain the governance costs that accompany excessive leverage in terms of pursuing highly risky strategies to maximize $\mathrm{ROE}^{8}$ and managerial rents. ${ }_{-}^{9}$

Despite significant progress to meet resolution objectives, concerns remain as to whether the present arrangements will work effectively in the event of a systemic crisis. Requisite skepticism centres on three key issues. First, whether bailing in the creditors of a cross-border institution, including the conversion of pre-funded liabilities in the guise of total loss-absorbing capital (TLAC) ${ }^{10}$ or minimum requirement for own funds and eligible liabilities (MREL), ${ }^{11}$

\footnotetext{
${ }^{4}$ Emilios Avgouleas \& Charles Goodhart, “A Critical Evaluation of Bail-Ins as Bank Recapitalisation Mechanisms” (2014) Centre for Economic Policy Research Discussion Paper No 10065, online: <http://ssrn.com/abstract=2478647>.

${ }^{5}$ Emilios Avgouleas, "Bank Leverage Ratios and Financial Stability: A Micro- and Macroprudential Perspective" (2015) University of Edinburgh Working Paper.

${ }^{6}$ AR Admati et al, "The Leverage Ratchet Effect" (2018) 73:1 J Finance 146 (first published as AR Admati et al, "The Leverage Ratchet Effect" (2013) Max Planck Institute for Research on Collective Goods Working Paper Series No 2013/13).

${ }^{7}$ For an estimation of the potential impact that a creditor bail-in would have, see Frank Packer \& Nikola Tarashev, "Rating Methodologies for Banks" (2011) BIS Q Rev 39; On the existence of the subsidy and calculations of its size and impact, see K Ueda \& B Weder Di Mauro, "Quantifying the Value of the Subsidy for Systemically Important Financial Institutions" (2011) IMF Working Paper No 12/128; R Gropp, H Hakenes \& I Schnabel, "Competition, Risk-shifting, and Public Bail-Out Policies" (2011) 24:6 Rev Financial Studies 2084; Z Li, S Qu \& J Zhang, "Quantifying the Value of Implicit Government Guarantees for Large Financial Institutions" (2011) Moody's Analytics Quantitative Research Group White Paper, online: <www. moodysanalytics.com/-/media/whitepaper/2011/2011-14-01-quantifying-the-value-of-implicit-governmentguarantees-for-large-financial-institutions-20110114.pdf>; João AC Santos, "Evidence from the Bond Market on Banks' 'Too-Big-To-Fail' Subsidy"' (2014) 20:2 Federal Reserve Bank of New York Economic Policy Review 29, online: <www.newyorkfed.org/medialibrary/media/research/epr/2014/EPRvol20no2.pdf>; Donald P Morgan \& Kevin J Stiroh, "Too Big to Fail After All These Years" (2005) Federal Reserve Bank of New York Staff Reports No 220, online:

<WWW.newyorkfed.org/medialibrary/media/research/staff_reports/sr220.pdf>; Zoe Tsesmelidakis \& Robert C Merton, "The Value of Implicit Guarantees" (2012) Working Paper, online:

$<$ http://ssrn.com/abstract=2231317>.

${ }^{8}$ See Admati, supra note 6; AR Admati et al, "Debt Overhang and Capital Regulation" (2012) Rock Center for Corporate Governance at Stanford University Working Paper No 114; E Avgouleas \& J Cullen, "Market Discipline and EU Corporate Governance Reform in the Banking Sector: Merits, Fallacies, and Cognitive Boundaries" (2014) 41:1 JL\& Soc'y 28.

${ }^{9}$ See E Avgouleas \& J Cullen, "Excessive Leverage and Bankers' Pay: Governance and Financial Stability Costs of a Symbiotic Relationship" (2014) 21:1 Colum J Eur L 1.

${ }^{10}$ See FSB, "Total Loss-Absorbing Capacity Principles and Term Sheet" (9 November 2015), online: <www.fsb.org/2015/11/total-loss-absorbing-capacity-tlac-principles-and-term-sheet/>.

${ }^{11}$ Under the Bank Recovery and Resolution Directive (BRRD) (art 45) and derivative legislation, EU banks must have a minimum cushion of regulatory capital and eligible liabilities expressed as a percentage of the total liabilities and own funds of the institution (MREL), which is the EU way of implementing the FSB TLAC standard. Doubts persist, however, as to whether MREL can cure the weaknesses of the EU resolution framework. See E Avgouleas \& C Goodhart, “An Anatomy of Bank Bail-ins: Why the Eurozone Needs a Fiscal
} 
would prove sufficient to prevent the bailout of a global systemically important financial institution (G-SIFI). Second, there are possible undesirable consequences associated with bailins when the failure is systemic rather than idiosyncratic. These issues are discussed at great length in our earlier publications. ${ }^{12}$ A third concern is whether there is sufficient liquidity to support a bank resolution. While this concern is pertinent to G-SIFI failures, the liquidity arrangements of domestic banks in resolution can also be unclear.

Other aspects of the resolution debate focus on the time horizon for the valuation of failing banks' losses ${ }^{13}$ and the possibility of managerial and regulatory forbearance when there are fears that bailing-in bank creditors in an unstable market may heighten contagion. Another concern is the extent to which the reformed resolution regimes are sufficient to mitigate moral hazard, especially in the absence of an ex post penalty regime for bank managers. ${ }^{14}$

The last issue also relates to the question of whether current resolution regimes are premised on clear normative objectives. While the latter might sound more theoretical than practical, it is, in our view, a matter of cardinal importance. The normative values attached to any public policy regime are not merely expressed in its statutory objectives but also reflect and signal its implicit values, rationales and expected utilities. This lack of clarity and the overlapping and sometimes conflicting nature of resolution objectives under present frameworks are a key part of this chapter's analysis.

Accordingly, this chapter is divided into three sections following the present introduction. The second section unbundles the normative objectives of contemporary resolution regimes, highlighting inconsistencies and shortcomings. In this context, we advocate a more relaxed approach to the provision of liquidity in resolution to avoid fire sales or when relying on depressed valuations influenced by fire sales. The third section focuses on the implications of draconian creditor bail-in regimes and the timing of valuations. The fourth section concludes.

Backstop for the Banking Sector" (2016) 2:2 Eur Economy 75, online: <http://european-economy.eu/2016-2/ananatomy-of-bank-bail-ins-why-the-eurozone-needs-a-fiscal-backstop-for-the-banking-sector/>; Tobias H Tröger, "Too Complex to Work: A Critical Assessment of the Bail-in Tool under the European Bank Recovery and Resolution Regime" (2018) 4:1 J Financial Reg 35.

${ }^{12}$ E Avgouleas \& C Goodhart, "Critical Reflections on Bank Bail-ins" (2015) 1:1 J Financial Reg 3, online: <https://academic.oup.com/jfr/article/1/1/3/2357875>.

${ }^{13}$ Uncertainty concerning overall losses is associated with the timing and method of calculation of the value of bank assets with discrepancies between valuation when the bank enters resolution and at certain fixed points in future when the same assets might have recovered for some value. Thus, the timing of valuation is a matter of fundamental importance not just for the distribution of bank losses but also for observing the "no creditor worse off" (NCWO) principle.

${ }^{14}$ See Steven L Schwarcz, "Too Big to Fool: Moral Hazard, Bailouts, and Corporate Responsibility” (2017) 102:2 Minn L Rev 761; Charles Nolan, Plutarchos Sakellaris \& John D Tsoukalas, "Optimal Bailouts of Systemic Banks” (2017) Adam Smith Business School University of Glasgow Working Paper. 


\section{Express and Implicit Objectives of Bank Resolution Regimes: The State of Confusion}

\section{The Microprudential Dimension}

Arguably the foremost objectives of bank resolution regimes are microprudential, regardless of the resolution technique that authorities choose to resolve a bank. The first microprudential goal is securing an orderly exit through an expedited legal process involving the restructuring, sale or liquidation of the affected institution and/or pre-accumulated debt cushions (for example, contingent convertibles [CoCos], TLAC and MREL) that can be converted into equity to recapitalize the bank or written-off to absorb losses. The second microprudential objective of a bank resolution regime is the ex_ante improvement of bank governance by augmenting risk controls and limiting leverage. This can be achieved by the close monitoring of creditors who want to avoid the cost of a bail-in. In addition, the risk of being bailed-in means that creditors ask a higher return for the money they lend to the bank raising the cost of bank funding enough to eliminate the TBTF subsidy. ${ }^{15}$ In contrast, inefficient bank resolution regimes can frustrate the impact of prudential rules that regulate capital and liquidity reserves, lending policies and large exposures, management quality and decision_making, and systems and controls within going concern banks. A third microprudential objective is securing bank recovery ${ }^{16}$ to avoid moving the bank into disruptive resolution.

\section{The Systemic/Macroprudential Dimension}

Legal and regulatory regimes that mitigate contagion from bank failures inevitably have a systemic/macroprudential dimension. Peter Muelbert observes that resolution regimes have a macroprudential/systemic objective although they are not part of prudential regimes. ${ }^{17}$ For this reason, the systemic dimension of resolution regimes may be underestimated focusing instead on private sector participation to ameliorate moral hazard. For this reason, insufficient attention has been given to interconnectedness risks in resolutions and the impact of resolution actions on investor, creditor and depositor confidence and the subsequent reactions of these constituencies, which can inadvertently propagate contagion. There are two reasons for this shortcoming. First, bank resolution techniques are exclusively microprudential with few

\footnotetext{
${ }^{15}$ For a first study of creditor reaction to a reduction of the possibility of bailouts on creditor reaction, see Alexander Schäfer_et al, "Bail-in expectations for European banks: Actions speak louder than words" (2016) European Systemic Risk Board Working Paper Series No 7.

${ }^{16}$ CAE Goodhart \& MA Segoviano, "An approach for initiating interventions for bank recovery" (2017) 25:4 J Financial Ref \& Compliance 360.

${ }^{17}$ Peter O Muelbert, "Managing Risk in the Financial System" in Niamh Moloney, Eilis Ferran \& Jennifer Payne, eds, The Oxford Handbook of Financial Regulation (Oxford, UK: Oxford University Press, 2015) 364 at 384.
} 
exemptions due to systemic concerns. ${ }^{18}$ Second, most regimes lack clear liquidity or "funding in resolution" arrangements ${ }_{2}{ }^{19}$ although the provision of liquidity to prevent fire sales or valuations based on fire sales are effective stabilizing measures. Conversely, frictions in the supply of liquidity could result in contagion from either counterparty defaults or fire sales. ${ }^{20}$ In this context, we regard the Bank of England's determination to provide sufficient liquidity during the resolution period, subject to the Her Majesty's (HM) Treasury indemnity, as appropriate. ${ }^{21}$ However the United States, and more recently the European Union, have decided not to give central banks the power to supply resolution liquidity, opting instead for US Treasury and European Stability Mechanism (ESM) loans, which may be harder to obtain.

\section{The Moral/Normative Dimension: A Political Economy Analysis}

Resolution regimes have a number of explicit and implicit moral/normative goals that flow from or overlap with the aforementioned micro and macroprudential aspects of resolution regimes. The first is mitigating moral hazard, based on the desire to force banks to internalize operational costs by following the "polluter pays" principle, for example, curbing the TBTF subsidy and eliminating the possibility of public bailouts. The second moral/normative goal is to restore market discipline by restricting the funding of bailouts and other advantages pertaining to TBTF banks. From this flows a third moral goal, namely the Schumpeterian cycle. A properly calibrated resolution regime should facilitate the market exit of failing underperforming banks, while providing opportunities for new market entrants. The Schumpeterian cycle theorizes that underperformers would otherwise be sustained by public subsidies. Indeed, the expeditious and orderly exit of underperformers or restructuring in a controlled environment are important for overall economic efficiency, market competition characterized by a "level playing field" and the attainment of transparent capitalism.

\footnotetext{
${ }^{18}$ For analysis of this point, see Steven L Schwarcz, "Beyond Bankruptcy: Resolution as a Macroprudential Regulatory Tool” (2019) 94:2 Notre Dame L Rev 709.

${ }^{19}$ A shortcoming that is highlighted in the FSB reports on the implementation of the "Key Attributes." See FSB, "Resilience through Resolvability — Moving from Policy Design to Implementation: Fifth Report to the G20 on Progress in Resolution" (18 August 2016) at 15, online: <www.fsb.org/wp-content/uploads/Resilience-throughresolvability-moving-from-policy-design-to-implementation.pdf >.

${ }^{20}$ See Emilios Avgouleas, "Fundamentals of Bank Supervision and the Lender of Last Resort in the Post-2008 Era: A Critical Appraisal and Forward Looking Recommendations" (2016) Edinburgh School of Law Research Paper No 2016, online: 〈https://papers.ssrn.com/sol3/papers.cfm?abstract_id=2833891>.

${ }^{21}$ See Bank of England, “The Bank of England's Approach to Resolution” (October 2017) at 22, box 2, online: <www.bankofengland.co.uk/-/media/boe/files/news/2017/october/the-bank-of-england-approach-toresolution.pdf?la=en\&hash=FC806900972DDE7246AD8CD1DF8B8C324BE7652F>.
} 
The fourth apparent normative goal is the "punishment" of placid creditors. The implicit moral goals that flow from the microprudential and macroprudential aspects of the regime require interpretation, predominantly from a political economic analysis perspective. Thus, they are subject to dispute and none more than the apparent "punitive" nature of the regime. ${ }^{22}$ _If the goal of the regime is, however, the containment of moral hazard, a punitive aspect may be inevitable for deterrence purposes. But instead of merely relying on super-rational and expert creditors, who can play the role of effective bank management monitors - admittedly a minority among bank creditors - resolution regimes should target the two constituents: bank management and large shareholders whose opportunistic behaviour is the key source of moral hazard. Furthermore, the punitive aspects of the bail-in may prove counterproductive in the context_of resolution frameworks that should primarily focus on orderly exit. They may incentivize bank management to delay the resolution process for as long as possible, if their views can influence regulators' decisions. In addition, the question remains as to who should be "punished": the incompetent, the unlucky, the rent-seekers or the risk-takers? Shifting the cost of bank failures from taxpayers to bank creditors via bail-ins, often means nothing other than a fundamental shift of this cost from one social group to another. ${ }^{23}$ The punitive approach would nonetheless be better defended if it was targeting bank management and large shareholders, even by means of ex post penalties.

Finally, the competitive pricing of banks' funding to reflect true levels of bank riskiness, since bail-in regimes remove the shield of bailouts from senior creditors, may have some impact on shareholder and management appetite for risk and leverage, which seem to be symbiotic. ${ }^{24}$ Thus, it may reinforce market discipline and make banks safer. However, it may not prove as effective as anticipated unless complemented by a prudential regime that is geared towards boosting equity buffers.

Interest rates are critical for the level of risk assumed by banks and for attracting capital investment in the banks. A sustained period of very low interest rates typically leads to riskier lending with higher yields to keep the banks' ROE ratios from collapsing. This predictable lending behaviour also leads to the accumulation of concealed risks on banks' balance sheets. At the same time, a long period of ultra-low interest rates eats into banks' profitability and makes bank equity a less than attractive investment. In a crisis ${ }_{2}$ low interest rates and relatively

\footnotetext{
${ }^{22}$ Cf Tobias H Tröger, "Too Complex to Work: A Critical Assessment of the Bail-in Tool under the European Bank Recovery and Resolution Regime" (2018) 4:1 J Financial Reg 35. Tröger doubts the punitive dimension of creditor bail-in regimes.

${ }^{23}$ Avgouleas \& Goodhart, supra note 12.

${ }^{24}$ AR Admati et al, supra note 6; Avgouleas \& Cullen, supra note 9.
} 
high costs of equity funding may prove more critical to banks' risk-taking behaviour and solvency than the TBTF subsidy.

Taxation regimes also impact on the cost of equity in a way that influences the mix of bank funding, capital structure and leverage even when the TBTF subsidy is diminished. ${ }^{25}$ Moreover, operating efficiencies, technological advantages, investment in research and development, client networks, economies of scale and scope also create funding advantages. Similarly, the level of market dominance ${ }^{26}$ is the result of a combination of factors as already mentioned and not just the result of the TBTF subsidy or of its absence.

\section{Bail-in's Moral Hazard, Post-resolution Challenges and Some Remedies}

\section{Bail-in's Moral Hazard}

The goals of the bail-in process are different in each jurisdiction. In the United States, the process for a bail-in and conversion of creditor claims is embedded in the resolution regime for systemically important financial institutions (SIFIs), the so-called Orderly Liquidation Authority (OLA). ${ }^{27}$ When a bail-in process is triggered under Title II of the Dodd-Frank Act the aim is to provide sufficient capital buffers for a subsidiary company to continue operations following the liquidation of its holding company. Nonetheless, the feasibility of the OLA process has not been tested during a crisis. ${ }^{28}$

In the European Union, on the other hand, the "doom-loop" between bank instability and sovereign indebtedness has presented member state governments with a major problem.

\footnotetext{
${ }^{25}$ See AR Anat et al, "Fallacies, Irrelevant Facts, and Myths in the Discussion of Capital Regulation: Why Bank Equity Is Not Socially Expensive" (2013) Stanford Business School Working Paper 2013; AR Admati \& Martin F Hellwig, The Bankers' New Clothes: What's Wrong with Banking and What to Do About It (Princeton, NJ: Princeton University Press, 2013).

${ }^{26}$ A Saunders \& I Walter, "Financial Architecture, Systemic Risk, and Universal Banking” (2012) 26:1 Fin Markets \& Portfolio Mgt 39; J Hughes \& L Mester, "Who Said Large Banks Don't Experience Scale Economies? Evidence from a Risk-Return-Driven Cost Function" (2013) 22:4 J Financial Intermediation 559; DC Wheelock \& PW Wilson, "Do Large Banks Have Lower Costs? New Estimates of Returns to Scale for U.S. Banks” (2013) 44:1 J Money, Credit \& Banking 171; A Kovner, J Vickery \& L Zhou, "Do Big Banks Have Lower Operating Costs?" (2014) 20:2 Federal Reserve Bank of Economic Policy Review 1 (“quantitatively, a 10 percent increase in assets is associated with 0.3 to 0.6 percent decline in noninterest expense scaled by income or assets, depending on specification" at 2). For a critical review of these studies, see Emilios Avgouleas, "Large Systemic Banks and Fractional Reserve Banking: Intractable Dilemmas in Search of Effective Solutions" in Ross P Buckley, Emilios Avgouleas \& Douglas W Arner, eds, Reconceptualising Global Finance and Its Regulation (Cambridge, UK: Cambridge University Press, 2016) 279.

${ }^{27}$ Supra note 3.

${ }^{28}$ P Kupiec \& P Wallison, "Can the 'Single Point of Entry_ Strategy be used to Recapitalize a Failing Bank?" (2014) American Enterprise Institute Working Paper No 8.
} 
Despite the establishment of the $\mathrm{ESM}^{29}$ which could have offered a limited fiscal backstop to the European Banking Union (EBU), bank recapitalisation in resolution relies on bailing-in bank liabilities. The EU resolution regime, based on the EU BRRD and the ESM statute, ${ }^{30}$ require bank creditors to cover the cost of a bank resolution up to eight percent of bank liabilities prior to any public contributions. This type of bail-in ${ }_{2}$ with designated and general liabilities $_{2}$ is thought to be sufficient to cover the cost of bank failures and to sever the links between bank and sovereign indebtedness.

One of the biggest challenges facing modern resolution regimes is incentivizing regulators and management to act ex ante when confronting problematic assets, especially non-performing loans (NPLs). Experience shows that when banks face high levels of NPLs, for example due to a preceding asset bubble (for example, Spain and Ireland) or because of adverse macroeconomic conditions (for example, Greece and Italy), regulators tend to act more expeditiously when the introduction of a fiscal backstop, normally in the form of a state-backed bad bank (for example, Sweden, Spain and Ireland) is being considered. ${ }^{31}$ In contrast, an outright bail-in of creditors could raise concerns that could delay the triggering of resolution. The absence of punitive, ex post bank management sanctions, as suggested by Stephen L. Schwarcz and analytically discussed by Charles Nolan, Plutarchos Sakellaris and John D. Tsoukalas, ${ }^{32}$ amounts to a major loophole. Resolution regimes, in their current form, do not address in full managerial incentives ${ }^{33}$ resulting in a bail-in process which could propagate managerial forbearance. The most important problem in this context is not that management might conceal NPLs, since regulatory monitoring mechanisms are quite effective; it is the impact on regulatory decision_making that management's unwillingness to reduce capital by excessively writing-off NPLs may have.

An even bigger problem is a scenario where public authorities, fearing the systemic implications of a bail-in regime, opt for publicly funded solutions. An example is when, in an adverse macroeconomic environment, the accumulation of NPLs and other non-performing bank exposures (NPEs) arise from a combination of systemic (macroeconomic) and idiosyncratic factors. The fear that a bail-in could result in a loss of market confidence might force authorities to offer a reprieve to creditors of institutions where high accumulation of

\footnotetext{
${ }^{29}$ Intergovernmental Treaty Establishing the European Stability Mechanism, Euro-area member states (2 February 2012) T/ESM 2012/en 2.

${ }^{30}$ ESM, "By-Laws", 8 October 2012, online: <www.esm.europa.eu/sites/default/files/esm_by-laws.pdf〉.

${ }^{31}$ See Douglas W Arner, Emilios Avgouleas \& Evan Gibson, “Overstating Moral Hazard: Lessons from Two

Decades of Banking Crises” (2017) University of Hong Kong Faculty of Law Research Paper No 2017/003.

${ }^{32}$ Schwarcz, supra note 14; Nolan, Sakellaris \& Tsoukalas, supra note 14.

33 Ibid.
} 
NPLs are mostly due to idiosyncratic factors, for example, when NPL levels in one bank are much higher than in other similar institutions. A good example here is the partial bailout of Monte dei Paschi di Sienna (MPS), which provided relief to retail creditors from a publicly funded "precautionary recapitalization" scheme to avoid triggering resolution under the BRRD $($ art. 32(4)(1)(d)), which would have resulted in a mandatory eight percent minimum bail-in of the bank's liabilities. ${ }^{34}$ The existence of a large amount of retail bondholders, in part due to mis-selling, ${ }^{35}$ was a very important factor looming large in the minds of law-makers complicating decision-making even further, since the same bondholders also held an important chunk of Italian bank shares and comprised the bulk of bank depositors. Therefore, Italian authorities were faced with a very substantial risk of a systemic bank run for which the BRRD framework was affording no flexibility in the course of taking resolution (bail-in action).

The Banca d'Italia graph, ${ }^{36}$ reproduced in Figure 1, reveals that in the years leading up to the 2017 "early recapitalisation," the accumulation of NPLs in MPS was twice the level of NPL growth in the rest of the Italian banking sector. Thus, the bailout of MPS would have been hard to justify without reference to the effect that a bail-in of senior creditors would have had on the confidence of Italian bank shareholders. ${ }^{37}$ Therefore, an inflexible bail-in process heightens rather than mitigates moral hazard. In fact, this is a situation that may be caused by rigid bailregimes regardless of the composition of the bank creditor body. For example, whereas a retail bondholder run was delayed until the last minute, and eventually, prevented inspite of the flaws of the MPS recapitalisation process, ${ }^{38}$ institutional holders of bail-inable debt would have run earlier and faster creating a downward spiral for all Italian banks, if it was them who held the bulk of Italian bank debt.

\footnotetext{
${ }^{34}$ EC, "State Aid 47677: New aid and amended restructuring plan of Banca Monte dei Paschi di Siena" (2017) 4690 final, 17.

${ }^{35}$ See S. Micossi, “Testing the EU Framework for the Recovery and Resolution of Banks: the Italian Experience", LUISS SEP Policy Brief - February 15, 2019.

${ }^{36}$ See Carmelo Barbagallo, Banca Monte dei Paschi di Sienna (Rome, Banking and Financial Supervision Department of the Bank of Italy, 2017), online: <www.bancaditalia.it/pubblicazioni/interventi-vari/int-var2017/Barbagallo-22112017.pdf $>$.

37 The subsequent performance of Italian banking stocks reinforces this view. As a relevant BIS study states: "Overall, the FTSE Italia All Share Banks index climbed by 10\% from the beginning of June to the end of July, outperforming the STOXX Europe 600 Banks index, which returned nearly 5\%." See Bilyana Bogdanova \& Mathias Drehmann, "How did markets react to bank distress in Europe?" (2017) BIS Q Rev, online: <www.bis.org/publ/qtrpdf/r_qt1709u.htm>.

${ }^{38}$ For excellent analysis of the problems raised by the relevant investor (bondholder) compensation arrangements see Micossi, supra note 35 at 10-12.
} 
Figure 1: Ratio between NPLs and Total Loans for MPS and the Rest of the Italian Banking Sector, 2007-2016

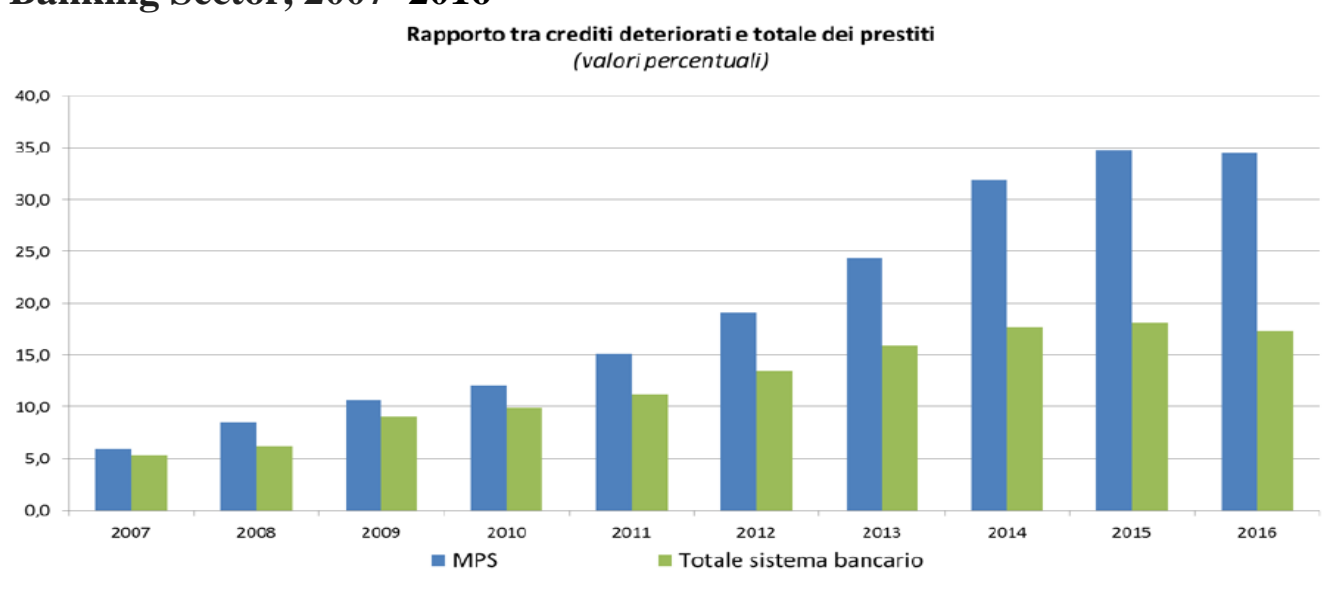

Source: Barbagallo, supra note 36 at 19.

Another good example is the winding down of the two Veneto banks in June 2017, as part of a wider rescue plan for the Italian banking sector. Veneto Banca (also associated with a misselling scandal) and Banca Popolare di Vicenza were wound down under controversial circumstances. The Single Resolution Board $\left(\mathrm{SRB}_{2}\right)$ held that the public interest test, when applying the BRRD regime, ${ }^{39}$ was not satisfied. ${ }^{40}$ In particular, the SRB held that: "[N]either of these banks provides critical functions, and their failure is not expected to have significant adverse impact on financial stability." ${ }^{41}$ Both banks were wound down by applying insolvency proceedings under Italian bankruptcy law. The controversial injection of government money was approved by the European Commission on the basis of a private sector solution - selling

\footnotetext{
${ }^{39}$ BRRD, supra note 2, art 32(1), (5); EC, Regulation (EU) No 806/2014 of the European Parliament and of the Council of 15 July 2014 establishing uniform rules and a uniform procedure for the resolution of credit institutions and certain investment firms in the framework of a Single Resolution Mechanism and a Single Resolution Fund and amending Regulation (EU), [2015] No 1093/2010 at art 18(1) 9c.

${ }^{40}$ SRB, "Decision of the Single Resolution Board concerning the assessment of the conditions for resolution in respect of Veneto Banca SpA" (2017) SRB/EES/2017/11, 11-21; SRB, "Decision of the SRB concerning the assessment of the conditions for resolution in respect of Banca Popolare di Vicenza SpA" (2017) SRB/EES/2017/12 [SRB, "Decision of the SRB"].

${ }^{41}$ SRB, "Decision of the SRB", supra note 38.
} 
the "good" parts of the insolvent banks to Intesa San Paolo, Italy's largest bank. ${ }^{42}$ The senior bondholders of both banks were transferred to Intesa San Paolo and were not bailed_in. A decision to wind_up both banks independently of the EU resolution framework was criticized by the European Parliament. ${ }^{43}$ But given the inflexibility of BRRD's eight percent requirement, this was necessary to prevent the collapse of the Italian banking sector. Figure 2 is indicative of the stabilizing effect that the Italian plan had on stock prices and bond spreads. ${ }^{44}$

\section{Figure 2: No Contagion from Bank Failures in Europe}

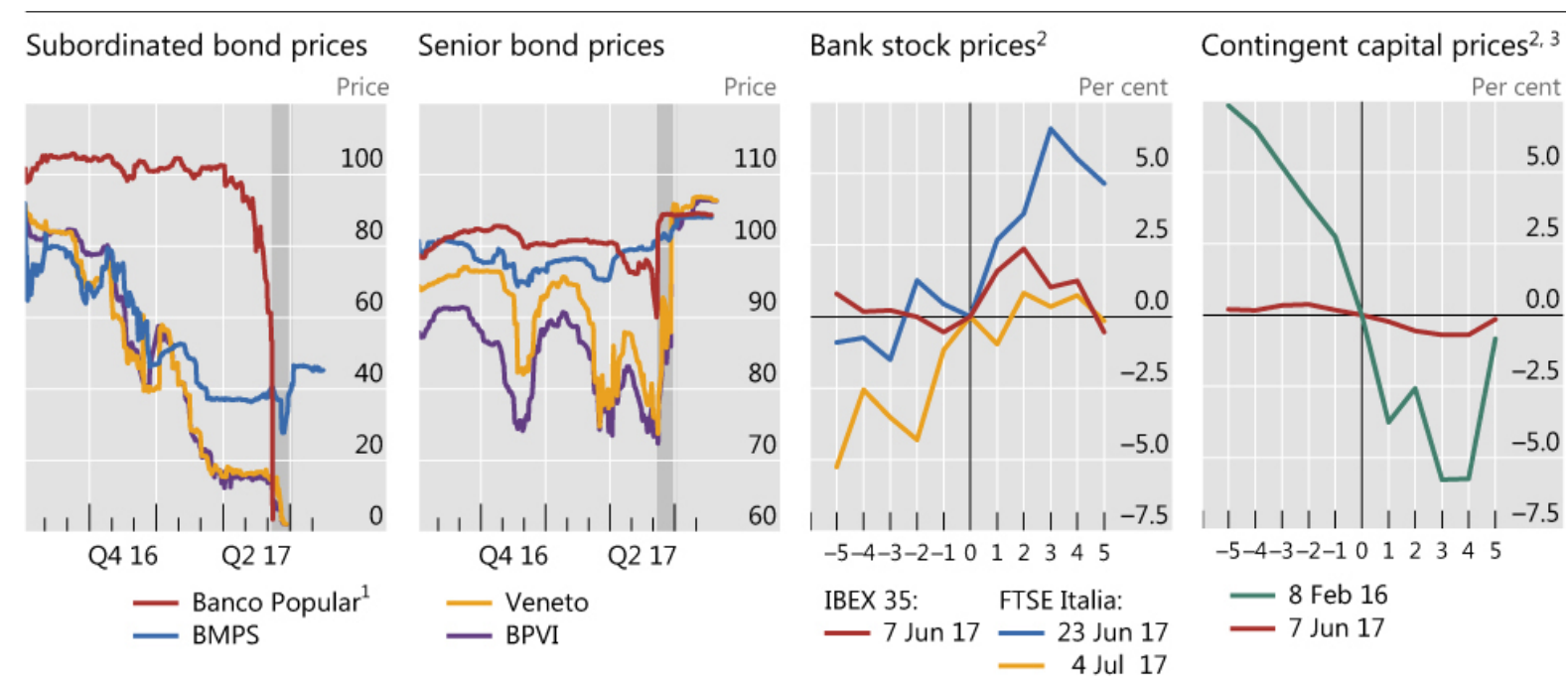

The shaded areas in the first two panels indicate the period 7 June to 4 July 2017.

1 For subordinated debt, AT1 contingent capital instrument. 2 Percentage changes over the stated window. Zero indicates the following event dates: 8 February 2016 (Deutsche Bank's statement on AT1 payments capacity), 7 June 2017 (the Single Resolution Board's (SRB's) endorsement of the resolution scheme for Banco Popular Español), 23 June 2017 (the SRB's resolution decision on Banca Popolare di Vicenza and Veneto Banca) and 4 July 2017 (the European Commission's approval of a precautionary recapitalisation for Banca Monte dei Paschi di Siena. ${ }^{3}$ Markit iBoxx USD liquid developed markets AT1 contingent capital index.

Source: Bloomberg.

Bank for International Settlements

Source: Bloomberg.

At the same time, the NPL accumulation ratio for the two Veneto banks was substantially more than double that of the, see Banca d'Italia's graph reproduced in Figure $3 .{ }^{45}$

\footnotetext{
${ }^{42}$ EC, "State Aid 45664: Orderly liquidation of Banca Popolare di Vicenza and Veneto Banca - Liquidation aid" (2017) 4501 final, 20-24.

${ }^{43}$ European Parliament, "The orderly liquidation of Veneto Banca and Banca Popolare di Vicenza" (2017)

Economic Governance Support Unit Briefing No PE 602 094, online:

<www.europarl.europa.eu/RegData/etudes/BRIE/2017/602094/IPOL_BRI(2017)602094_EN.pdf>.

${ }^{44}$ Bogdanova \& Drehmann, supra note 37.

${ }^{45}$ Carmelo Barbagallo, Veneto Banca e Banca Popolare di Vicenza (Rome: Banking and Financial Supervision Department of the Bank of Italy, 2017) at 18, online: <www.bancaditalia.it/pubblicazioni/interventi-vari/int-var2017/barbagallo-audizione-02112017.pdf >.
} 


\section{Figure 3: Ratio between NPLs and Total Loans of the Veneto Banca, Popolare di Vicenza and the Rest of the Italian Banking Sector, 2007-2016}

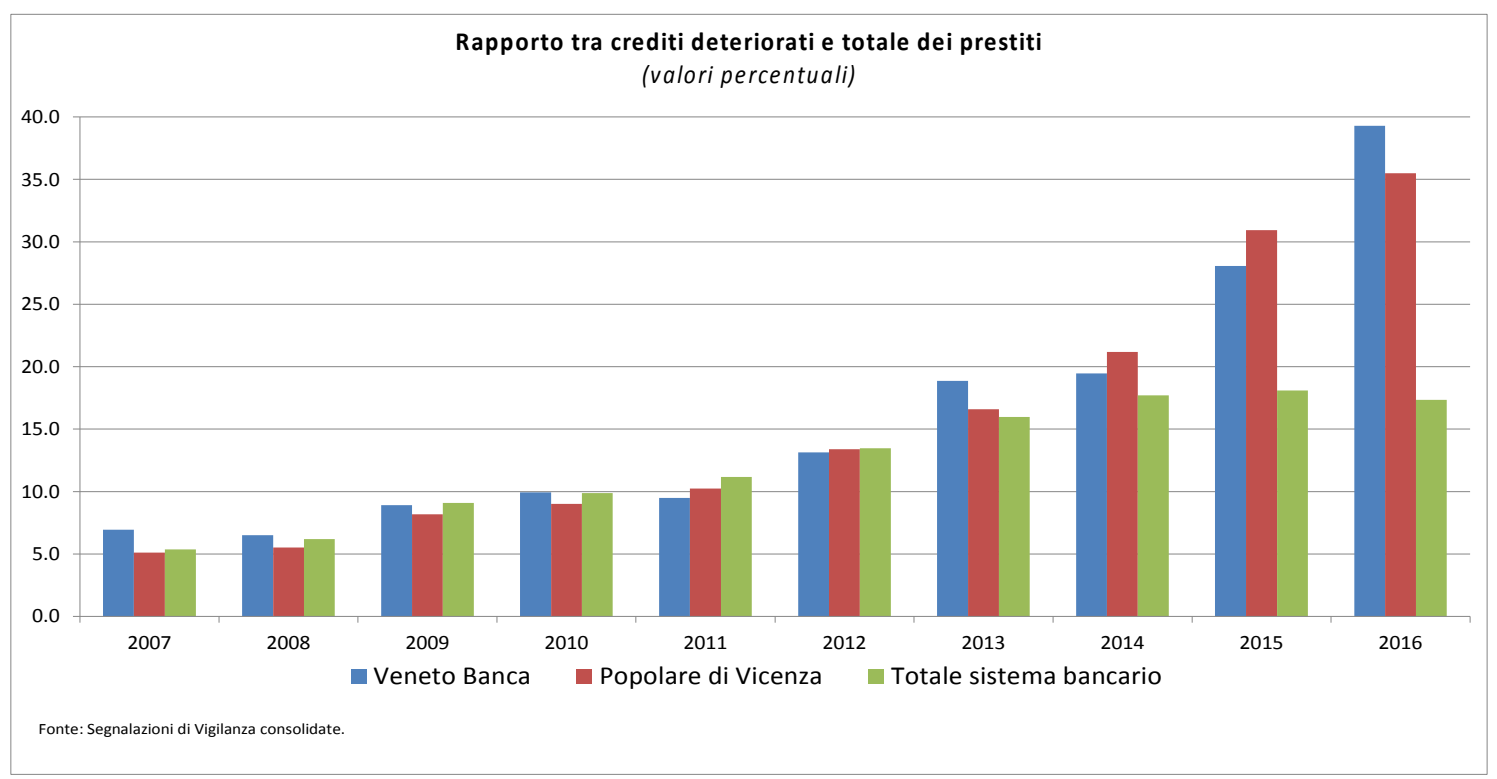

Source: Barbagallo, supra note 45 at 18.

These examples, and especially the rescue of MPS, demonstrate that draconian bail-in regimes can have serious undesirable consequences that can weaken rather than strengthen market discipline.

Moreover, all forms of insurance raise the issue of moral hazard. The certainty that sufficient specially designated liabilities, such as CoCos (i.e., for a going-concern bank), TLAC and MREL, once resolution has been triggered, will be in place to provide adequate loss absorption is no exception. For example, convertible debt capital cushions proved insufficient to prevent the insolvency of the two Veneto banks nor did they prevent Spain's Banco Popular from entering into resolution. ${ }^{46}$ Specifically, in an effort to keep the two Veneto banks solvent, subordinated debt capital was converted in 2015 before the injection of public funds and in 2017 prior to the banks being wound down. Then Banco Popular's supervisors forced the

\footnotetext{
${ }^{46}$ See European Parliament, "The resolution of Banco Popular” (2017) Economic Governance Support Unit Briefing No PE 602.093, online: <www.europarl.europa.eu/RegData/etudes/BRIE/2017/602093/IPOL_BRI (2017)602093_EN.pdf>.
} 
conversion of all Common Equity Tier 1 and Additional Tier 1 (AT1), including CoCos, in June 2017 to prevent the bank's collapse. This did not prevent a resolution action being instigated by the SRB as the bank had insufficient provisions for bad assets ${ }^{47}$ and its capital buffers, including the convertible component, proved to be inadequate. So, a private sector sale was required to keep the bank from being liquidated. This prompted a groundswell of litigation from junior bondholders who were either written-off (AT1) or converted (Tier 2). ${ }^{48}$ In all of these cases no further creditor bail-in action was taken.

\section{The Critical Matter of Asset Valuation in Resolution}

The bail-in process cannot properly function unless bank losses are identified in a finite form. Bank losses, including unrealized future losses, must be accurately determined to avoid successive rounds of bail-in losses accruing to bank creditors. This can be challenging in practice. For example, bank losses have been consistently underestimated, both in the Global Financial Crisis and subsequently in the European crisis. The valuation of assets is an inexact science and market cyclicality further complicates the appraisal task. ${ }^{49}$ In the uncertain conditions when the market is experiencing generalized asset value declines, the new (incoming) accountants, employed by the resolution agency, are likely to take a bad or a worstcase scenario as their baseline for identifying losses. Previously, the accountants of the failing bank itself would have been encouraged (by management) to take a more positive view of the value of its assets. Thus, the transition from the bank's accountants to those of the resolution authority is likely to cause a huge discontinuity in the form of a massive drop in published accounting valuations. Furthermore, there is the issue of a potential rise in the valuation of bank assets once the first shock has subsided. This may also be found by factoring in the difference between the current market value of the failing bank's assets and their long-term economic value, though, admittedly, the latter is a controversial concept.

\footnotetext{
47 Ibid at 2.

48 See T Hale, "Investors sue Brussels over Banco Popular sale", FT.com (17 August 2017), online: <www.ft.com/content/b96003b4-8335-11e7-94e2-c5b903247afd> ("International investors have launched legal action against the European authorities that oversaw the failure of Banco Popular, in the latest attempt to overturn the decisions that led to the bank's sale to Santander in June for $€ 1$ ”); F Guarascio, "Investors file 51 lawsuits against EU for shutting Banco Popular", Reuters.com (30 August 2017), online: <www.reuters.com/article/bancopopular-ma-investors/investors-file-51-lawsuits-against-eu-for-shutting-bancopopular-idUSL8N1LF3BA> ("Disgruntled investors have filed 51 lawsuits against European Union regulators for shutting Spain's Banco Popular, marking one of the largest legal challenges yet to the EU and a fresh attack on the bloc's rules on bank rescues. The deluge of cases, filed with the European Union's General Court, are the first legal test of how the EU applies new bank rules aimed at forcing investors to bear the costs of rescuing a failing lender before taxpayer money is used").

${ }^{49}$ Bank failures during boom conditions (resulting from fraud, such as Barings, for example) are easier to handle, with less risk of contagion.
} 
The difference in valuations during different time periods is critical when it comes to assessing conformity with the NCWO principle. The reason for this is twofold. First, in an insolvency, creditors' losses are judged ex post once the firm has been liquidated or sold and the assets have been disposed of, whereas in a resolution, bank losses are determined either when the bank enters into resolution or shortly thereafter. Asset prices in resolution are normally marked against a depressed market, and both bank sales and asset sales are bound to attract a limited number of buyers, which compromises the concept of competitive market prices. The possibility of discrepancies in valuations upon entry into resolution and ex post valuations is also recognized by European Banking Authority (EBA), which clarifies that the definitive valuation will be the ex post one where a definitive valuation upon entry to resolution is not possible. ${ }^{50}$ The BRRD and EBA's technical standards recognize the ex post valuation approach is important when determining whether "shareholders and creditors do not receive worse treatment under resolution than they would have expected in a counterfactual liquidation under normal insolvency proceedings." 51 Martin Hellwig notes, in a recent study for the EU Parliament, that even this approach will not resolve the problem of attaching realistic calculations to an NCWO test. ${ }^{52}$

\footnotetext{
${ }^{50}$ EBA, Draft Handbook on Valuation for Purposes of Resolution (2018), online: $<$ https://eba.europa.eu/documents/ 10180/2120596/2018+11+12+-+Draft+Valuation+Handbook+-+clean.pdf/918db9fa-c951-494f-b51b-
} af2e119797b5 ("To enable the [Resolution Authority] to take action also in circumstances of urgency...the BRRD envisages the possibility for resolution action to be adopted also on the basis of a provisional valuation (Art. 36(2) and (9))....Such valuation consists of two steps: the first requiring the subdivision of creditors into classes, the second establishing an estimate of the treatment that such classes would receive should the institution be put in insolvency...An ex-post definitive valuation is envisaged when the resolution decision has been informed on the basis of a provisional valuation (Article 36_(10) BRRD). The provisional and the ex-post definitive valuation...may yield different results, having regard to the higher granularity of the available information, the valuation approach adopted and the time available.... The ex-post definitive valuation may rely on data and information not available to the valuer or the RA when performing the provisional valuation...In accordance with Article 6(e) of that Regulation, the valuation report should explain the differences between the methodologies and assumptions used in the provisional and in the ex-post definitive valuation" at 14-15).

${ }^{51}$ The EBA Regulatory Technical Standards on valuations in resolution note: "[T]he assumptions governing the estimation of the treatment that shareholders or creditors would have received in insolvency are driven by the sole purpose of determining the appropriate discounted value of cash flows that could reasonably be expected under the relevant national insolvency procedures." EBA, "RTS on Valuation in Resolution, Final Draft: Regulatory Technical Standards on Valuation for the purposes of resolution and on valuation to determine difference in treatment following resolution under Directive 2014/59/EU on recovery and resolution of credit institutions and investment firms," EBA/RTS/2017/05, EBA/RTS/2017/06 at 6, online:

<https://eba.europa.eu/documents/10180/1853532/Final+draft+RTSs+on+valuation+in+resolution+\%28EBARTS-2017-05+\%26+EBA-RTS-2017-06\%29.pdf>.

52 Martin F Hellwig, "Valuation reports in the context of banking resolution: What are the challenges? Banking Union Scrutiny" (2018) EP In-depth Analysis PE624.417, online:

<www.europarl.europa.eu/RegData/etudes/IDAN/2018/624417/IPOL_IDA(2018)

624417_EN.pdf> ("First, in a resolution procedure, one may never learn what investors' payouts in a counterfactual insolvency procedure would have been. Indeed, the very resolution decision that is taken may preclude the attainment of such information by anybody. For example, when the sale-of-business tool is used, 
Beyond the application of the NCWO principle, there are_other often neglected systemic implications attached to valuation in resolution. A pessimistic valuation will result in much deeper write-downs, write-offs or conversion haircuts, with the ensuing creditor losses being greater than previously anticipated based on the valuation assumptions of the pre-resolution auditors. This could lead investors to question the valuations of other banks, leading to a rapid deterioration in confidence and a contagious crisis.

One solution is to freeze payouts ${ }^{53}$ given that an additional backstop is provided by deposit insurance. A temporary moratorium of payments on asset disposals would require a robust liquidity support mechanism to avoid severe side effects. These side effects include consequential defaults, for example large corporations needing access to deposits, a panic or even a bank run. ${ }^{54}$ With the BRRD and the SRM Regulation silent on resolution funding, the European Council recently gave the Single Resolution Fund (SRF) the power to borrow from the ESM (from 2024) to fund resolution actions. ${ }^{55}$ This arrangement follows the Dodd-Frank Act resolution funding arrangements where the Federal Deposit Insurance Corporation can obtain resolution funding by borrowing from the US Treasury. Whether this decision offers an effective solution to the problem of "funding resolution" is doubtful given the limited size of the fund and the conditions to mitigate moral hazard imposed by the ESM. ${ }^{56}$

Either way, subjectivity and arbitrariness when measuring risk and the illiquidity of nontradable assets will remain, especially when assessing conditional probability distributions of future returns based on unreliable data. Markets may rebound following a downturn to provide reliable mark-to-market data, but in the absence of an arbitrary cut-off date, forbearance is no panacea.

\footnotetext{
the bank and its assets are likely to be integrated into the purchaser's business so that no additional information about the assets, let alone the proceeds of a potential liquidation is generated" at 13-14).

${ }^{53} \mathrm{~A}$ temporary freeze on payments is discussed in the Bank of England's approach to resolution.

${ }^{54}$ Hellwig. supra note 52 at 15.

${ }^{55}$ The heads of state and government of the 19 Euro-area countries endorsed a package of proposals on deepening the Economic and Monetary Union (EMU) at the Euro Summit on 14 December 2018. Proposals included the introduction of the common backstop for the SRF provided by the ESM.

${ }^{56}$ The size of the credit line will be aligned with the SRF funds, which by 2024 will be around $€ 60$ billion, or one percent of covered deposits in the Banking Union. If the credit line is used, the SRF will pay back the ESM loan with money from bank contributions within three years, although this period can be extended up to another two years. Disbursements under the common backstop will be approved by the ESM board of directors, consisting of high-level officials from the 19 Euro-area finance ministries, by mutual agreement. Procedures will be in place so that such approval can be made swiftly and efficiently (in as little as 12 hours)_in strict confidentiality because of the sensitive nature of the data. The council realized that the funding was inadequate, and the issue of "liquidity provision in resolution" will be discussed further in 2019.
} 


\section{Liquidity Support in Resolution}

The EU approach to bail-ins increases the significance of liquidity support. The European Council decision to allow the ESM to lend money to the SRF to fund resolutions is important in acknowledging the existence of the problem. It is also a positive step that ESM provision of liquidity to the SRF will not be subject to ESM conditionality like sovereign funding. However, this facility will be limited by the size of the SRF reserves. We suggest that further liquidity could be provided by the ECB either to each legal entity, against the entity's collateral available to that entity, or channelled through a parent company. Typically, a G-SIFI is funded mostly through retail and other short-term deposits, which, in the event of a bail-in, could either dry up or even be withdrawn. Thus, a G-SIFI in resolution may require considerable official liquidity support. This should only be provided on a fully collateralized basis, with appropriate haircuts applied to the collateral, to reduce the risk of loss, but this depends on the adequacy of available collateral.

Lender of last resort (LoLR) liquidity is provided alongside other measures to stabilize a failing bank. These financial stability measures may not prevent the bank from entering resolution. The United Kingdom has a liquidity framework that allows HM Treasury to indemnify the central bank (Bank of England) when a loss is incurred from funding a bank in resolution (for example, a bridge bank). ${ }^{57}$ If a central bank provides liquidity to fund a resolution, this may not qualify as LoLR finance but rather as state aid, which could require high-grade collateral. By this stage of the resolution process, some bank assets will be impaired, and the scope of central bank liquidity provided to a bank entering resolution would be uncertain, especially in the absence of a state indemnity facility.

The BRRD provides that resolution is primarily financed by national resolution funds that can also borrow from each other. ${ }^{58}$ The Deposit Guarantee Scheme (DGS) ${ }^{59}$ will have to contribute for the purpose of ensuring continuous access to covered deposits and the requisite contributions will be in cash for an amount equivalent to the losses that the DGS would have had to bear in normal insolvency proceedings. Namely, the DGS contribution is made in cash in order to absorb the losses incurred from the covered deposits. ${ }^{60}$ The DGS is solely liable for

\footnotetext{
${ }^{57}$ See HM Treasury, "Banking Act 2009: Special Resolution Regime code of practice"_(12 March 2015), online: <www.gov.uk/government/publications/banking-act-2009-revised-special-resolution-regime-code-of-practice>; EC, Commission Delegated Regulation (EU) 2015/63 of 21 October 2014 supplementing Directive 2014/59/EU of the European Parliament and of the Council with regard to ex ante contributions to resolution financing arrangements [2015] OJ, L 11/44.

58 BRRD, supra note 2, art 99ff.

${ }^{59}$ BRRD, supra note 2, arts 45(6), 108(b), 109, recs 71, 110, 111.

${ }^{60}$ BRRD, supra note 2, art 109(3).
} 
the protection afforded to covered depositors. ${ }^{61}$ If following a contribution by the DGS, the institution under resolution fails at a later stage, and the DGS does not have sufficient funds to repay depositors, the DGS must have arrangements in place in order to raise the corresponding amounts expeditiously from its members. Otherwise, treating the DGS as an unsecured creditor in the event of a systemic crisis might raise doubts concerning the availability of sufficient funds.

At this stage of the resolution process, robust LOLR liquidity support would mitigate the risk of a fire sale and therefore it would contain systemic risk spillovers. Depressed market prices due to fire sales have an adverse effect on the value of the wider banking sector, especially in an environment where bank balance sheets are rather homogeneous. In our view, the UK's arrangements should also be followed in the EBU with an ESM backstop, in the form of a longterm indemnity, offered to the ECB to provide liquidity in resolution, whenever other arrangements for down-streaming liquidity come short.

\section{Post bail-in bank funding}

Market confidence in the bailed-in institution would have to be quickly restored_in order to preserve franchise value and reimburse official liquidity support. ${ }^{62}$ This is mostly dependent on how fast the bank's capital structure will be rebuilt or the establishment of a strongly capitalized new bank in the event of a "closed" bank process. If an institution has entered into a death spiral and becomes subject to a run with customers, creditors and depositors all fast disappearing, reversing this trend would doubtless prove a daunting task.

Under the BRRD's open bank procedure, reliance on the creditor bail-in process to recapitalize banks can result in several funding rounds including post-resolution rounds. For example, a bail-in involving the Portuguese Novo Banco bank resulted in the creation of a "good bank" from the resolution of the failed Espirito Santo bank. ${ }^{63}$ Nonetheless successive bail-in rounds can alarm investors when market funding is needed to resolve a bank, or its successors, to full financial health.

Policy_makers tend to underestimate the dynamics of a bank run ex post, even where creditors face no potential losses in the aftermath of a resolution action. This is due, presumably, to

\footnotetext{
${ }^{61}$ BRRD, supra note 2, art 109(1).

${ }^{62}$ See Joseph H Sommer, "Why Bail-In? And How!” (2014) 20:2 Federal Reserve Bank of New York Econ Pol Rev 207.

${ }^{63}$ For example, senior creditors of Novo Banco had to suffer further bail-in rounds despite the steep haircut applied to junior creditors who absorbed the losses of the bad bank. See M Arnold \& Thomas Hale, "ECB under fire as Portugal hits Novo Banco bondholders", FT.com (7 Jan 2016); Christopher Whittall, "Investors File Suit Against Bank of Portugal Over Novo Banco", WSJ.com (5 April 2016).
} 
reputation risks and the (possibly irrational) fear of future financial difficulties. ${ }^{64}$ The dynamic is much greater when banks and creditors have experienced large losses from the triggering of, and subsequent, bail-in rounds. ${ }^{65}$

Resolution regimes that aim to restore systemic stability to serve their macroprudential objectives should also address the question of what happens when a bank exits the resolution stage, post-bail-in, and is returned to the regulator's custody, but market funding for it remains scarce. ${ }^{66}$ While the aim of the bail-in is that the bank itself (in the EU framework) or its successor exit resolution as a going concern, ${ }^{67}$ the possibility that the bank might face market reluctance to fund it, for example, due to reputation shocks and funders' behavioural constraints, ${ }^{68}$ should not be discounted.

There are two possible approaches to post-resolution funding. The first would use the central bank to provide liquidity support as the LoLR. Arguably, liquidity support in this case could lead to avoidance of future bail-in rounds ${ }^{69}$ and thus act as a solvency prop. In addition, LoLR funding at this early stage would come with a certain stigma attached. The second is funding the post-resolution bank through a pre-committed collateralised facility.

In the opinion of the first author this could be done through fully collateralised bonds issued post-resolution to institutional investors that have committed to funding the facility ex ante. ${ }^{70}$ Such a facility has the dual advantage of preventing any post-resolution creditor runs while substantially resolving the bank funding needs. The costs of such a funding scheme would depend on how successful the preceding resolution has been augmenting the incentives of the resolution authority and other relevant parties to handle resolutions with due concern to ex post market reactions. The second approach is also a fiscally neutral position, even though in the case of the EBU the ESM could be used as a guarantor of the first tranche of such bonds, which, however, would inevitably result in over-collateralisation.

\section{Conclusion}

This chapter has offered a systematic analysis of the reformed bank resolution regimes

\footnotetext{
${ }^{64}$ See Mark Carlson \& Jonathan Rose, "Can a Bank Run Be Stopped? Government Guarantees and the Run on Continental Illinois” (2016) BIS Working Papers No 554, online:<www.bis.org/publ/work554.pdf〉.

${ }^{65}$ Arnold \& Hale, supra note 63; Christopher Whittall, supra note 63.

${ }^{66}$ For a wider discussion, see Avgouleas, supra note 20.

${ }^{67}$ BRRD, supra note 2, art 43(2)(a).

${ }^{68}$ For insightful analysis of this problem, see Carlson \& Rose, supra note 64.

${ }^{69}$ Avgouleas, supra note 20.

${ }^{70}$ This idea matured in the context of some intensive email exchanges between the first author and senior ESM director and esteemed colleague Mike Hesketh in the weeks preceding Mike's sudden death (+2 May 2019) and pays tribute to Mike's preliminary work on post-resolution bank funding.
} 
implemented during the post-global financial crisis period. In this context, the chapter has considered the key objectives underpinning the new resolution regimes. Despite the progress made in key jurisdictions (for example, the United States, the United Kingdom and the European Union) the chapter has identified persistent problems with the application of contemporary resolution frameworks especially in the European Union. It has also highlighted the confusing nature of the explicit and implicit objectives pursued by reformed resolution regimes. Relevant analysis has particularly focused on the shortcomings of bail-in regimes in the pursuit of macroprudential objectives and the mitigation of moral hazard. Funding in resolution requires a more liberal liquidity regime to provide the desired stabilizing effect. However, resolution regimes per se cannot stabilize the banking system. Tax regime reforms, ex post penalties for bank management, increasing the liability of key shareholders and measuring more accurately the impact of very low interest rates on bank balance sheets are all equally important elements that need to be considered to ameliorate the TBTF effect and strengthen financial stability. 